\title{
Pengaruh Pelatihan Konsep Diri terhadap Kecenderungan Pembelian Impulsif pada Remaja Akhir di Kabupaten Tulungagung
}

\section{The Effect of Self-concept Training on Impulsive Buying Tendencies for Adolescents in Tulungagung}

\author{
Putri Dwi Aliyati ${ }^{*}$, IGAA. Noviekayati ${ }^{1}$, Muhammad Farid ${ }^{1}$ \\ ${ }^{1}$ Program Studi Magister Psikologi, Universitas 17 Agustus 1945 Surabaya \\ *putrida s2@untag-sby.ac.id
}

\begin{abstract}
Abstrak
Tujuan dari penelitian ini adalah mengetahui pengaruh pelatihan konsep diri terhadap kecenderungan pembelian impulsif pada remaja akhir di Tulungagung. Penelitian ini menggunakan metode penelitian eksperimen randomized two group design posttest only dengan sample remaja akhir usia 18-20 tahun sebanyak 20 orang, yaitu 10 orang pada kelompok eksperimen dan 10 orang pada kelompok kontrol. Post test menggunakan skala kecenderungan pembelian impulsif Verplanken dan Herabadi dengan reliabilitas 0.9. Setelah diberikan pelatihan konsep diri dan post test skala kecenderungan pembelian impulsif, hasil perhitungan statistik dengan analisis independent $t$-test menunjukkan nilai sig $=0.158$ ( $>0.05)$ yang berarti bahwa tidak ada pengaruh pelatihan konsep diri terhadap kecenderungan pembelian impulsif.
\end{abstract}

Kata kunci: Pembelian Impulsif, Konsep Diri

\begin{abstract}
The purpose of this study is to determine the effect of self-concept training on impulsive buying tendencies for adolescents in Tulungagung. This study using randomized two groups design posttest only - method or using 2 groups design posttest with the sample of the age between 18-20 years old, 10 people for each groups, experiment and control group. Post-test uses the scale of impulsive buying tendencies Verplanken and Herabadi with a reliability of 0.9. After being given self-concept training and post-test with impulsive buying tendency scale, the results of statistics ccomputation with independent $t$-test analysis method show that value of sig $=0.158(p>0.05)$ which means that there is no effect of selfconcept training on the tendency of impulsive buying.
\end{abstract}

Keywords: Impulsive Buying, Self - Concept

\section{Pendahuluan}

Minat konsumsi masyarakat semakin hari semakin meningkat. Industri makanan, fashion yang berupa pakaian dan make up, kendaraan, barang elektronik dan pariwisata seolah tidak hentinya berkembang dari skala Usaha Kecil Menengah (UKM) hingga perusahaan besar berskala nasional. Tempat-tempat wisata dan kafe pun ramai dipenuhi konsumen, baik yang memang bertujuan melakukan pembelian maupun hanya sekadar singgah untuk menghabiskan waktu. Toko-toko yang menyediakan berbagai merk handphone hingga produk-produk fashion juga selalu ramai dikunjungi konsumen.

Menikmati kopi di gerai kopi langganan kini juga sedang menjadi tren. Pertumbuhan gerai kopi modern tahun 2018 terlihat melonjak tinggi dan menjamur di berbagai daerah di Indonesia. Dikutip dari Financial Times, di Indonesia jumlah kedai kopi artisan dan gerai kopi meningkat dua kali lipat dalam lima tahun terakhir (Maharani, 2018). Gaya hidup tersebut juga mempengaruhi minat beli masyarakat. Pembeli yang sebelumnya tidak ingin membeli makanan, beralih melakukan pembelian untuk menghabiskan waktu di coffee shop atau tempat nongkrong tersebut. 
Tidak hanya di warung atau toko, bisnis ritel tersebut mulai merambah di internet yang dikenal sebagai E-Commerce, dimana distribusi, pemasaran, pembelian dan pembayaran semuanya diakses melalui internet yang bahkan bisa dilakukan oleh individu melalui smart phone. Menurut data Google \& Temasek pada 2017, pembelian produk lewat e-commerce di Indonesia mencapai 146,7 triliun rupiah. Pembelian tersebut naik 41 persen, yakni dari angka sekitar 74 triliun rupiah pada 2015 dan diprediksi akan naik setiap tahunnya (Iskandar, 2018).

Smartphone yang terhubung secara online dengan aplikasi belanja, konsumen juga dengan leluasa dapat memesan produk kecantikan, pakaian dan kebutuhan rumah tangga dari rumah sehingga proses pembelian bisa lebih mudah, sehingga tanpa sadar konsumen juga membeli produk-produk yang tidak terlalu dibutuhkan, karena banyaknya iklan dan penawaran.

Menurut harian kompas jumlah pembeli online di Indonesia meningkat selama beberapa tahun terakhir. Pada ahun 2018, jumlah konseumen yang berbelanja online diperkirakan mencapai 11,9 persen dari total populasi di Indonesia. Data tersebut bersumber dari lembaga statistik internasional bernama Statista (Putera, 2018).

Pada beberapa uraian yang telah dijelaskan oleh peneliti menunjukkan bahwa aktivitas belanja sudah menjadi perilaku pembelian yang konsumtif. Data yang dipaparkan oleh Otoritas Jasa Keuangan (OJK) menunjukkan bahwa masyarakat Indonesia semakin konsumtif dan mulai meninggalkan kebiasaan menabung. Hal itu terlihat dari menurunnya Marginal Propensity to Save (MPS) dan naiknya Marginal Prosperity to Consume (MPC) selama tahun 2011 sampai 2013, yang artinya masyarakat lebih banyak mengeluarkan uang untuk konsumsi daripada ditabung (Jatmiko, 2015). Perilaku pembelian tersebut dilakukan karena berbagai hal dari pembelian yang sangat terencana sampai yang tidak terencana.

Pola konsumtif tersebut secara masal nyata terjadi di sekeliling kita. Bagaimana seringnya konsumen membeli sesuatu walaupun belum tentu benar-benar membutuhkannya. sehingga pada proses pembelian yang seharusnya bersifat rasional, konsumen melakukannya tanpa merencanakannya terlebih dahulu atau cenderung impulsif.

Tinarbuko (dalam Henrietta, 2012) menyebutkan beberapa faktor yang mempengaruhi perilaku dan pola hidup konsumtif, di antaranya adalah harga diri, gengsi, status sosial, ekonomi, pengaruh teman, dan tingkat pendididikan.

Samhadi (dalam Henrietta, 2012) menyatakan bahwa berbagai strategi pemasaran yang agresif juga membuat masyarakat semakin terjebak dalam arus gaya hidup konsumtif yang dapat menyebabkan terjadinya perilaku impulse buying atau pembelian impulsif.

Pembelian impulsif dapat didefinisikan sebagai dorongan spontan dan tidak direncanakan untuk melakukan pembelian tanpa ada pikiran untuk mempertimbangkan mengapa atau apa alasan individu yang bersangkutan harus melakukan pembelian (Vohs \& Faber, 2007). Pembelian impulsif disisi lain juga merupakan tindakan yang diakui tidak secara sadar sebagai hasil dari suatu pertimbangan pembelian sebelum memasuki toko, yaitu desakan hati secara tiba-tiba dan tanpa rencana untuk membeli sesuatu secara langsung tanpa banyak memperhatikan akibat dari pembelian tersebut (Mowen \& Minor, 2002)

Penelitian dan berbagai studi telah dilakukan terhadap mekanisme yang bertanggung jawab atas kata hati tiba-tiba, dan menunjukkan bahwa sekitar 39 persen dari pembelian toko serba ada dan 67 persen dari pembelian toko sandang pangan adalah pembelian yang tidak direncanakan. Pembelian ini juga disebabkan usaha konsumen untuk memperoleh pengalaman baru dan pengalaman yang berbeda (Mowen \& Minor, 2002).

Pembelian impulsif bagaikan dua sisi mata pedang, jika porsinya tidak tepat negara juga akan dirugikan. Pembelian impulsif mengacu pada gaya hidup konsumtif dimana perekonomian negara akan lebih menggeliat jika retail dan industri dalam negeri dapat berjalan dengan baik, namun jika permintaan pasar berlebihan dan tidak tepat sasaran, produksi dalam negeri akan kewalahan sehingga negara harus mengimpor produk atau bahan baku untuk memenuhinya.

Budi Hikmat, Direktur Investment Strategy Bahana PT TCW Investment Management menjelaskan dalam sebuah wawancara, perilaku konsumtif masyarakat Indonesia ternyata turut menyumbang depresiasi nilai tukar rupiah terhadap dollar Amerika Serikat, terutama konsumsi produk impor (Fauzia, 2018).

Tingginya konsumsi menunjukkan bahwa ketika masyarakat memiliki uang, mereka akan lebih mengutamakan belanja daripada ditabung. Jika terjadi dalam jangka panjang akan berpengaruh terhadap ketersediaan dana di perbankan, padahal dana tersebut dapat dimanfaatkan untuk menopang 
pertumbuhan ekonomi nasional dan tidak perlu mencari pendanaan dari luar negeri untuk membiayai pembangunan ekonomi, membangun infrastruktur dan sebagainya (Jatmiko, 2015).

Pembelian impulsif juga memiliki dampak yang cukup merugikan secara psikologis. Hal ini didukung oleh pernyataan Rook bahwa konsumen yang melakukan pembelian impulsif mengalami dampak negatif seperti permasalahan keuangan, perasaan menyesal dan bersalah setelah membeli produk, dan seringkali tidak mendapatkan persetujuan oleh orang di sekitarnya terhadap produk yang sudah dibeli walaupun bagi pelaku industri pembelian secara spontan tersebut akan sangat menguntungkan toko (Rook, 1987).

Seperti yang dijelaskan dalam penelitian Dell'osso (Dell'osso, dkk., 2008), pembelian impulsif merupakan gambaran awal dari Impulsive-Compulsive buying disorder yang digambarkan oleh psikiatri Jerman, Emil Kraepelin sebagai Oniomania atau yang merupakan suatu disorder atau kekacauan dan kelainan dalam perilaku pembelian. Walaupun demikian, dalam beberapa kasus perilaku pembelian impulsif dilihat sebagai perilaku yang tidak terkontrol dan epidemik awal dari mental disorder, namun belum dapat digolongkan dalam perilaku patologis.

Berbelanja merupakan aktivitas yang dilakukan oleh konsumen yakni pergi ke sebuah toko atau tempat untuk berjual beli untuk memenuhi kebutuhannya, dengan membeli suatu produk atau jasa. Usaha atas pemenuhan kebutuhan konsumen tersebut dipengaruhi oleh faktor internal dan eksternal. Faktor eksternal meliputi budaya, status sosial, keluarga dan lain sebagainya. Sedangkan faktor internal dipengaruhi oleh adanya keinginan atau motif yang mendasari konsumen untuk memenuhi kebutuhannya tersebut (Ibrahim \& Ng, 2002).

Hawkins (Hawkins, dkk., 2001) menyatakan motif sebagai suatu konsep yang mewakili suatu dorongan dari dalam yang tidak dapat diobservasi yang merangsang dan mendorong suatu tanggapan perilaku dan menyediakan arahan khusus dalam terhadap tanggapan tersebut.

Penelitian yang dilakukan oleh Oping dkk (Oping dkk, 2015) menjelaskan bahwa motivasi memiliki pengaruh terhadap pembelian impulsif dengan nillai koefisien yang signifikan. Berdasarkan hasil uji statistik dapat dijelaskan bahwa motivasi misalnya seperti dorongan kebutuhan dasar, rasa haus dan lapar, keamanan, kebutuhan psikologis serta kebutuhan sosial sangat berpengaruh terhadap pembelian impulsif (Oping dkk, 2015).

Adapun beberapa faktor lain yang dapat mempengaruhi pembelian impulsif adalah faktor demografis seperti usia, jenis kelamin dan tingkat penghasilan menjadi penyebab yang penting dalam pembelian impulsif dan penyelesaian transaksi pembelian. Tingkat pembelian impulsif pada konsumen yang berusia di bawah 35 tahun cenderung lebih tinggi dari usia lain. Begitu juga dengan jenis kelamin dan tingkat penghasilan. Wanita lebih cenderung melakukan pembelian impulsif daripada pria, serta individu yang memiliki penghasilan yang lebih tinggi, lebih banyak juga membelanjakan uangnya daripada individu yang berpenghasilan lebih rendah (Khawaja, 2018).

Pada penelitian ini, remaja menjadi fokus utama karena pada tahap kehidupannya, mereka belum memiliki penghasilan tetap dan mayoritas masih meminta uang dari orangtua. Hal ini akan menjadi masalah bila remaja tidak dapat mengontrol dorongan pembelian tersebut. Berdasarkan survey yang dikutip dari RetailingToday, 83 persen Millenial mengaku bahwa mereka pernah berbelanja secara impulsif (Swaratunaiku, 2016).

Fenomena ini dapat dilihat dari penelitian Enrico dkk (Enrico, dkk., 2004) bahwa keseharian remaja di kota metropolitan, bahwa remaja akan mencari pemenuhan dengan patokan standar sosial seperti memenuhi kebutuhan sosialnya dengan nongkrong di gerai kopi, kafe serta menghabiskan waktunya di mall bersama teman seusianya (Enrico, dkk., 2014). Di kota kecilpun, seringkali remaja menghabiskan waktu untuk nongkrong di warung kopi dan kafe hanya untuk menggunakan fitur wifi dan bercengkrama dengan teman sebaya sambil membeli makanan yang seharusnya tidak dibutuhkan.

Melihat kebebasan mereka membelanjakan uang tersebut menurut kehendak hati mereka merupakan hal yang problematik sebagai remaja karena lebih rentan terhadap ciri yang melibatkan kecenderungan pembelian impulsif (Virvilaite \& Saladine, 2012). Hal ini juga didukung oleh artikel dari CNN Indonesia bahwa perilaku yang tanpa berpikir kembali saat melakukan pembelian atau cenderung impulsif, dominan dilakukan oleh generasi millennial (Primadhyta, 2015) dengan menyebutkan angka sebesar 50 persen generasi milenial merupakan konsumen yang paling impulsif di Asia Pasifik.

Pembelian impulsif banyak menyebabkan hal-hal yang kurang baik untuk psikologis remaja. Seperti yang tergambar dalam peristiwa yang terjadi tahun 2018 di portal berita online. Seorang ibu paruh baya yang mengaku tercekik kebutuhan ekonomi menawarkan ginjalnya dengan harga murah di depan sebuah pusat perbelanjaan di Surabaya karena desakan anaknya yang meminta dibelikan ponsel (Aini \& Anisa, 2018). Dalam artikel berita tersebut, sang anak ingin memiliki ponsel tanpa 
menghiraukan keadaan ekonomi yang masih kurang. Padahal Handphone bukan merupakan bahan kebutuhan mendesak yang dapat ditukar dengan organ tubuh yang dapat mengancam nyawa.

Sama halnya yang terjadi di Bangkalan Madura, seorang remaja nekat mencuri motor untuk membeli ponsel (Mahesa, 2018) dan tiga remaja di Bandarlampung menjadi begal, yakni mencuri motor korban dengan cara menakut-nakuti menggunakan senjata api mainan (Muslihah, 2017). Motif yang dilakukan para remaja yang dijelaskan dalam artikel berita tersebut serupa yaitu untuk membeli barang yang diinginkan tanpa memikirkan kebutuhan dan keadaannya dengan kata lain pembelian secara impulsif, sehingga jelas pembelian impulsif memiliki dampak negatif bagi remaja yang belum memiliki kontrol diri yang penuh atas dirinya.

Pada penelitian Sciffman dan Kanuk (Sciffman \& Kanuk, 2004) memperlihatkan bahwa impulse buying dapat dipengaruhi oleh lingkungan toko dengan dimediasi oleh aspek emosi atau afeksi, sehingga konsumen yakni dalam penelitian ini adalah remaja, akan lebih tertarik secara afeksi dan emosi sehubungan dengan tahap perkembangannya.

Remaja akan berusaha mencapai originalitas serta menunjukkan pertentangan terhadap orang dewasa dan solidaritas teman-teman sebaya dalam prosesnya menuju tahap perkembangan selanjutnya sehingga cenderung menghabiskan waktu dengan membentuk kelompok teman sebaya. Proses perubahan perilaku atau sikap untuk lebih menyerupai suatu kelompok disebut dengan konformitas (Cialdini \& Goldstein, 2004).

Dalam pembelian impulsif pada remaja, perilaku tersebut yaitu self esteem juga memiliki pengaruh. Hasil penelitian dengan subyek mahasiswa Universitas Islam Bandung (Firdaus \& Yusuf, 2017) menyatakan bahwa semakin rendah tingkat self esteem mahasiswa akan semakin tinggi pula kecenderungan melakukan pembelian impulsif. Ini terlihat jelas pada salah satu aspek self esteem yaitu kemampuan dalam menilai dirinya sendiri merupakan aspek yang paling tinggi korelasi negatifnya dengan pembelian impulsif.

Demikian juga yang hasil penelitian dengan subyek mahasiswa tingkat awal yang dilakukan oleh Nisa' (Nisa', 2015) yaitu semakin positif konsep diri maka tingkat pembelian impulsif akan semakin rendah. Sebaliknya, semakin negatif konsep diri maka perilaku pembelian impulsif pada mahasiswa akan semakin tinggi. Sebaliknya, semakin Hal tersebut juga mencakup aspek konsep diri yang negatif yaitu, pesimis dalam berkompetisi dan tidak merasa setara dengan orang lain.

Hurlock (Hurlock, 1999) mengemukakan bahwa konsep diri adalah pandangan individu tentang dirinya yang disusun dari dua komponen pandangan yaitu konsep diri yang sebenarnya atau disebut dengan real self yang dapat diartikan sebagai gambaran tentang diri dan konsep diri ideal atau ideal self yang merupakan gambaran tentang kepribadian yang diinginkan individu tersebut. Konsep diri juga disebut sebagai bayangan cermin, dimana bayangan tersebut ditentukan dari peran dan hubungan dengan orang lain serta bagaimana reaksi orang terhadap diri.

Burns (Burns, 1993) menjelaskan individu yang memiliki konsep diri positif mengevaluasi diri sendiri dan meyakini dirinya sebagai seseorang yang berharga atau dengan kata lain memiliki penghargaan diri yang tinggi terhadap diri yang diwujudkan melalui perilaku.

Cooley (dalam Rakhmat, 2005) menyebutkan konsep diri dengan ciri looking glass self atau cermin diri. Individu seakan meletakkan cermin di depannya kemudian menilai dirinya sendiri. Pada konsumen, konsep diri berhubungan dengan kebahagiaan, keberuntungan, praktis, serius, pengendalian diri, kesuksesan, sensitif dan agresif yang secara umum diatur oleh dua prinsip yaitu keinginan untuk mencapai konsistensi dan keinginan utuk meningkatkan harga diri.

Peneliti berasumsi dari penelitian yang telah diuraikan sebelumnya, remaja yang belum memiliki penghargaan diri dan konsep diri yang ideal cenderung melakukan pembelian produk yang dirasa akan menaikkan harga diri dan konsep diri yang dituju tercapai. Remaja yang dalam tugas perkembangannya adalah memenuhi kebutuhan sosialnya dan memilih serta mempersiapkan karir untuk masa dewasanya (Desmita, 2011) akan lebih condong pada teman sebaya (Hurlock, 2004), sehingga konsep diri dibutuhkan untuk melakukan keputusan pembelian.

Adapun hal yang dapat mengurangi kecenderungan perilaku pembelian impulsif tersebut adalah dengan meningkatkan dan menerapkan konsep diri yang positif. Peneliti menerapkan pelatihan konsep diri dengan memfokuskan aspek-aspek konsep diri menurut Fitts (dalam Agustiani, 2009) yaitu tentang diri identitas, diri pelaku, diri penerimaan, diri fisik, diri etik-moral, diri pribadi, diri keluarga dan diri sosial.

Selain itu penerapan konsep diri positif pada remaja seperti yang dijelaskan oleh Burns (dalam Rakhmat, 2005) antara lain seperti yakin akan kemampuan dalam mengatasi masalah, merasa setara dengan orang lain, menerima pujian tanpa rasa malu, menyadari bahwa setiap orang memiliki berbagai 
perasaan, keinginan dan perilaku yang tidak seluruhnya disetujui masyarakat serta mampu memperbaiki dirinya dengan mengungkapkan aspek-aspek kepribadian yang tidak disenangi lalu berusaha mengubahnya.

Lokasi penelitian yang diambil adalah Kabupaten Tulungagung, di mana Tulungagung dari waktu ke waktu mengalami kenaikan perekonomian secara signifikan. Hal ini ditunjukkan dari data statistik dan ekonomi Dinas Komunikasi dan Informatika Kabupaten Tulungagung (2018) yang menunjukkan bahwa tahun 2017 Tulungagung memiliki Pendapatan Domestik Regional Bruto (PDRB) yaitu 24,64 trilyun pada tahun 2017 dan mengalami kenaikan dari tahun ke tahun sejak 2013. Peringkat Indeks Pembangunan Manusia (IPM) pada tahun 2017 juga menduduki peringkat 14 dari seluruh kabupaten di Jawa Timur.

Struktur perekonomian Tulungagung selama 5 tahun terakhir yaitu selama 2013-2017 didominasi oleh Industri pengolahan; pertanian, kehutanan dan perikanan; perdagangan besar dan eceran, reparasi mobil dan sepeda motor; serta konstruksi, informasi dan komunikasi. Di antara kelima lapangan usaha tersebut, industri pengolahan yang mendominasi dan lapangan perdagangan besar dan eceran, reparasi mobil dan sepeda motor; serta konstruksi, informasi dan komunikasi berfluktuasi namun cenderung mengalami peningkatan peranan (2018).

Peneliti juga berasumsi remaja akhir di kabupaten Tulungagung menghadapi masalah dalam keputusan pembelian, sebab Tulungagung merupakan kabupaten yang sedang berkembang. Dalam 2 tahun belakangan ini telah berdiri Pusat Perbelanjaan atau Mall dan gedung bioskop yang selalu dipenuhi oleh pengunjung yang sebagian besar adalah para remaja. Remaja akhir juga dihadapkan pada fenomena nongkrong dan kafe-kafe yang menjamur.

Terhitung lebih dari 100 kafe baik skala besar maupun kecil terlihat setiap hari dikunjungi oleh para remaja untuk membeli makanan dan minuman walaupun tidak terlalu dibutuhkan. Untuk itulah, peneliti ingin melakukan penelitian tentang pengaruh pelatihan konsep diri dengan mengacu pada teori Fitts (dalam Agustiani, 2009) dengan kecenderungan pembelian impulsif pada remaja akhir di Tulungagung.

\section{Metode Penelitian}

Metode dalam penelitian ini adalah eksperimen dengan membandingkan dua kelompok tanpa pretest atau randomized two-group posttest only (Seniati, dkk., 2011) serta menggunakan teknik pengambilan sampel accidental sampling (Sugiyono, 2009) yang dapat didefinisikann sebagai teknik pengambilan sampel secara kebetulan dengan memberi kesempatan kepada semua remaja akhir yang secara kebetulan bertemu dengan peneliti dan memenuhi kriteria sebagai sumber data.

Variabel $\mathrm{Y}$ atau variabel terikat dalam penelitian ini adalah kecenderungan pembelian impulsif atau impulse buying tendency yang merupakan kecenderungan perilaku yang berasal dari desakan tibatiba dan tanpa perencanaan serta tidak diakui secara sadar untuk membeli barang atau jasa tanpa banyak mempertimbangkan akibat selanjutnya.

Alat ukur yang digunakan adalah skala kecenderungan pembelian impulsif dikembangkan oleh Verplankern dan Herabadi (Verplanken., dkk, 2001) yang sudah diuji dengan realibilitas (Koefisien alfa) 0.91 (lampiran). Alat ukur tersebut terdiri dari dua aspek penting yaitu kognitif dan afektif yang dijabarkan dalam tabel 1.

Tabel 1. Indikator Kecennderungan Pembelian Impulsif

\footnotetext{
Kognitif Indikator

Aspek ini fokus terhadap konflik yang terjadi pada kognisi individu yaitu:

b. Kegiatan pembelian tanpa mempertimbangkan kegunaannya

Emosional atau afektif

Pada aspek ini fokus pada kondisi emosi individu, yang meliputi

a. Dorongan perasaan untuk segera melakukan pembelian seketika

b. Perasaan kecewa setelah melakukan pembelian

c. Proses pembelian dilakukan tanpa direncanakan terlebih dahulu
}

a. Kegiatan pembelian yang dilakukan tanpa mempertimbangkan harga suatu produk

c. Kegiatan dimana individu tidak melakukan perbandingan suatu produk dengan produk lainnya 
Sedangkan variabel $\mathrm{X}$ atau variabel bebas dalam penelitian ini adalah pelatihan konsep diri, yang merupakan serangkaian pelatihan untuk membantu individu menyadari dan menghargai cerminan atau gambaran diri yang dimilikinya, dimana konsep diri terbentuk melalui pengalaman yang didapat melalui interaksi dengan lingkungan di sekitarnya.

Adapun tahapan dalam pemilihan subyek adalah menentukan kriteria sampel penelitian yakni sampel dengan usia remaja akhir kemudian memilih 20 orang, yaitu 10 subyek dalam kelompok eksperimen dan 10 subyek dalam kelompok kontrol.

Tabel 2. Distribusi Jenis Kelamin Subyek

\begin{tabular}{ccc}
\hline Jenis Kelamin & Kelompok Eksperimen & Kelompok Kontrol \\
\hline Perempuan & 5 orang & 7 orang \\
Laki-laki & 5 orang & 3 orang \\
Total & 10 orang & 10 orang \\
\hline
\end{tabular}

Kelompok eksperimen diberikan pelatihan konsep diri yang didesain oleh penulis yang dilakukan selama 3 kali pertemuan. Tiap pertemuan terdiri dari 2 sesi dengan menggunakan metode psikoedukasi berupa ceramah, refleksi diri, presentasi dan permainan serta tanya jawab interaktif lalu diakhiri dengan mengukur kecenderungan pembelian impulsif. Sedangkan kelompok kontrol dengan kriteria yang sama diberikan skala kecenderungan pembelian impulsive tanpa perlakuan apapun.

\section{Hasil Penelitian}

Penelitian ini bertujuan untuk mengetahui pengaruh pelatihan konsep diri terhadap kecenderungan pembelian impulsif dengan subyek remaja akhir.

Hasil eksperimen dengan sampel berjumlah 20 orang yaitu 10 orang untuk kelompok kontrol dan 10 orang untuk kelompok eksperimen diperlihatkan pada tabel distribusi frekwensi tingkat kecenderungan pembelian impulsif antara kelompok kontrol dan kelompok eksperimen tabel 3 dan 4 .

Tabel 3. Distribusi Frekwensi Tingkat Kecenderungan Pembelian Impulsif

\begin{tabular}{ccc}
\hline Kategori & Rentang & Kel. Kontrol \\
\hline Sangat Rendah & $\mathrm{X}<20.005$ & $10 \%$ \\
Rendah & $20.005 \leq \mathrm{X}<33.335$ & $40 \%$ \\
Sedang & $33.335 \leq \mathrm{X}<46.665$ & $30 \%$ \\
Tinggi & $46.665 \leq \mathrm{X}<59.995$ & $20 \%$ \\
Sangat Tinggi & $\mathrm{X} \geq 59.995$ & $0 \%$ \\
\hline
\end{tabular}

Tabel 4. Distribusi Frekwensi Tingkat Kecenderungan Pembelian Impulsif

\begin{tabular}{ccc}
\hline Kategori & Rentang & Kel. Eksperimen \\
\hline Sangat Rendah & $\mathrm{X}<20.005$ & $10 \%$ \\
Rendah & $20.005 \leq \mathrm{X}<33.335$ & $40 \%$ \\
Sedang & $33.335 \leq \mathrm{X}<46.665$ & $30 \%$ \\
Tinggi & $46.665 \leq \mathrm{X}<59.995$ & $20 \%$ \\
Sangat Tinggi & $\mathrm{X} \geq 59.995$ & $0 \%$ \\
\hline
\end{tabular}

Hasil analisis data penelitian menggunakan independent $t$-test, diperoleh $\mathrm{t}=-1.474$ dengan nilai $S i g=$ 0.158 ( $p>0.05)$ yang berarti tidak ada pengaruh pelatihan konsep diri terhadap kecenderungan pembelian impulsif pada subyek.

\section{Pembahasan}

Dari hasil analisis data penelitian, menunjukkan bahwa tidak ada pengaruh pelatihan konsep diri terhadap kecenderungan pembelian impulsif ditunjukkan dengan tidak adanya perbedaan antara hasil posttest kelompok kontrol dan eksperimen. Pandangan subyek pada kelompok eksperimen dan kontrol tentang pembelian impulsif tidak terlalu memiliki perbedaan secara sigifikan walaupun kelompok 
eksperimen telah diberikan pelatihan konsep diri. Selain itu kategori nilai yang dihasilkan pada tiap kelompok adalah kategori sedang.

Menurut Seniati dkk (Seniati, 2011), hal ini dimungkinkan karena adanya proactive history atau beberapa faktor perbedaan individual yang dibawa ke dalam penelitian yang mungkin faktor-faktor tersebut telah dimiliki individu sebelum dilakukan penelitian dan ketika individu tersebut menjadi subyek penelitian seperti usia, jenis kelamin, kepribadian, sikap, intelegensi dan lain sebagainya.

Respon dari subyek ketika diberikan penelitian sangat beraneka ragam. Peneliti sudah memaksimalkan pengkondisian, dimana lokasi telah dirancang senyaman mungkin dengan suasana yang friendly dan santai untuk mengkondisikan perkembangan remaja akhir agar dapat memproses materi pelatihan, namun beberapa subyek terlihat kurang fokus pada pelatihan. Materi yang seharusnya bisa diterima secara utuh dan tidak diikuti dengan maksimal akan menyebabkan ketidaksamaan persepsi pada tiap subyek sehingga hasil posttest akan berbeda.

Hasil dari survey artikel menyebutkan bahwa remaja merupakan penyumbang tertinggi dalam pembelian impulsif (Swaratunaiku, 2016) dan remaja di kota metropolitan mencari pemenuhan kebutuhan sosialnya dengan nongkrong di kafe dan menghabiskan waktunya di mall bersama teman sebayanya (Enrico, dkk., 2014). Remaja di Tulungagung memiliki karakteristik serupa dengan yang digambarkan pada penelitian tersebut, namun hasil penelitian menunjukkan remaja Tulungagung berada pada kategori pembelian impulsif sedang. Hal tersebut dapat dipengaruhi oleh faktor latar belakang budaya.

Remaja yang tinggal di tengah kota cenderung lebih impulsif daripada yang tinggal di pinggiran, hal ini disebabkan karena faktor budaya dan pengetahuan akan produk baru, ketertarikan dan penghargaan konsumen kota lebih tinggi daripada yang tinggal di pinggiran (Virvilaite \& Saladiene, 2012) sehingga tingkat pembelian impulsif pada tiap subyek juga beraneka ragam sehingga menghasilkan rerata nilai sedang.

Sifat hedonistik juga merupakan faktor yang berpengaruh terhadap pembelian impulsif (Virvilaite \& Saladiene, 2012), yaitu semakin individu memiliki pandangan hidup dimana perasaan akan muncul ketiga berbelanja (hedonis) maka akan semakin tinggi pula tingkat kecenderungan pembelian impulsifnya. Remaja akhir yang belum memiliki penghasilan sendiri tidak akan memiliki sifat hedonis seperti individu yang sudah memiliki penghasilan sendiri, sehingga hasil kecenderungan pembelian impulsif remaja akhir yang tinggal di Tulungagung mendukung faktor-faktor yang telah dipaparkan.

Pembelian impulsif sendiri dipengaruhi oleh berbagai faktor-faktor internal dan eksternal. Faktor internal meliputi emosi (Rook \& Gardner, 1987), kognisi dan afeksi (Olson \& Peter, 2005). Mood atau suasana hati adalah bagian dari emosi. Terdapat penelitian yang menyatakan bahwa individu cenderung akan melakukan pembelian impulsif ketika sedang berada pada kondisi suasana hati yang bagus (Besouh \& Belkhir, 2018). Dalam penelitian ini, peneliti tidak dapat mengontrol bagaimana suasana hati subyek sesaat setelah pelatihan selesai. Sehingga hal ini kemungkinan dapat mempengaruhi hasil penilaian dirinya tentang kecenderungan pembelian impulsif.

Hal ini serupa dengan pernyataan pada dimensi afeksi pada pembelian impulsif yaitu pada aspek kepuasan, perasaan bergairah, bersemangat dan tertarik pada sesuatu (Verplanken \& Herabadi, 2001). Peneliti tidak bisa mengontrol suasana hati subyek sesaat setelah pelatihan karena pengisian alat ukur pembelian impulsif diberikan ketika subyek diberikan makanan dan reward oleh peneliti.

Terdapat faktor internal lain yang dapat mempengaruhi kecenderungan pembelian impulsif yaitu seperti pada penelitian Lesmana (2017) ditemukan adanya hubungan antara mindfulness dan pembelian impulsif pada remaja perempuan yang melakukan shopping online. Hal ini membuktikan peran mindfulness dalam proses pengambilan keputusan untuk membeli suatu barang. Mindfulness adalah kondisi atau keadaan pikiran yang sepenuhnya sadar terhadap apa yang sedang dilakukan dan berusaha untuk menyadari tentang berbagai hal yang terjadi baik di luar maupun di dalam diri, sedangkan pembelian impulsif merupakan suatu tindakan pembelian yang dilakukan karena kurangnya kesadaran dalam diri tentang keputusan yang diambil pada saat membeli suatu barang.

Vohs dan Baumeister (Vohs \& Baumeister 2011) mengidentifikasi karakteristik pembelian impulsif, yaitu keputusan yang cepat untuk melakukan pembelian, tidak atau kurang memperhatikan konsekwensi dan keputusan untuk membeli muncul melalui konflik antara keinginan serta kontrol dirinya. Adapun faktor seperti self control atau kontrol diri di sini juga sangat berpengaruh dalam keputusan untuk membeli secara impulsif atau tidak.

Adapun faktor-faktor eksternal yang mempengaruhi perubahan-perubahan pembelian impulsif pada remaja adalah ketersediaan waktu dan uang (kelas sosial), diskon dan suasana toko (Hatane \& Foedjiwati, 2005). Selain itu produk dengan karakteristik harga murah, kebutuhan kecil, produk jangka 
pendek dan toko yang mudah dijangkau (Loudon \& Bitta, 1993) juga memiliki pengaruh yang tinggi dalam pembelian impulsif. Peneliti kurang memperhatikan faktor-faktor eksternal tersebut, karena lebih mengedepankan perkembangan remaja akhir yang rata-rata memiliki kecenderungan yang sama yaitu tentang konsep diri dalam hal gambaran dirinya hingga pengambilan keputusannya.

Pemilihan karakteristik remaja akhir juga sudah dikontrol yaitu remaja akhir yang memang gemar berbelanja, data ini didapat dari data preliminary, dimana peneliti menanyai seluruh subyek dan disetujui oleh subyek. Namun beberapa faktor internal dan eksternal yang sudah dijelaskan sebelumnya juga perlu dikontrol untuk menghindari tidak berpengaruhnya pelatihan konsep diri yang diberikan.

Menurut Agustiani konsep diri individu dimulai dari usia balita. Individu mulai mengenali wajahnya hingga masuk pada perkembangan anak yaitu masa eksplorasi diri. Hingga pada usia awal remaja teman sebaya mulai memainakan peran dominan meggantikan orangtua sebagai orang yang berpengaruh pada konsep diri mereka. Memasuki usia remaja, individu akan mengalami perubahan hampir pada seluruh area kehidupan seperti ketidak tergatungannya pada orangtua (Agustiani, 2009). Pada usia remaja inilah terjadi perubahan yang drastis pada konsep diri.

Hingga pada masa menuju dewasa, remaja akan mulai bersiap menuju dunia kerja dan bekeluarga serta melakukan keputusan tanpa campur tangan dari orang yang lebih dewasa yaitu pada remaja akhir. Hal itu membutuhkan penyelesaian masalah-masalah sehingga melahirkan konsep diri orang dewasa (Agustiani, 2009). Dari penjelasan terebut konsep diri dalam perkembangan remaja akhir merupakan faktor yang penting dan akan terus berlanjut.

Permasalahan yang biasa dialami remaja adalah tentang pemahaman dirinya sekarang dan di masa depan, bagaimana mengembangkan identitas dan mengembangkan kecakapan untuk mengatasi berbagai pengambilan keputusan (Elias, dkk., 2004). Pembentukan konsep diri yang stabil akan memberikan pribadi generalisasi-generalisasi mengenai dirinya sendiri dengan dasar yang kokoh, sehingga pengambilan keputusan, tingkah laku dan reaksi yang diharapkan dari orang lain menjadi konsisten (Burns, 1993).

Salah satu masalah yang akan dialami oleh remaja adalah pengambilan keputusan dan kecenderungan pembelian impulsif merupakan salah satu masalah yang dihadapi ketika individu merasa telah diberikan tanggung jawab dalam pengambilan keputusan serta mengelola uang tanpa bantuan dari orangtua yang hubungannya ada pada keputusan pembelian. Sehingga asumsinya jika remaja memiliki konsep diri yang positif, remaja akan melakukan keputusan pembelian dengan tepat.

Selain itu juga terdapat jurnal penelitian tentang perbedaan konsep diri pada budaya dan pengaruhnya terhadap pembelian impulsif, yaitu bahwa konsep diri memiliki peranan (Kacen \& Lee, 2002) dimana individu dengan konsep diri yang independen atau independent self concept akan cenderung lebih impulsif untuk membelanjakan uangnya.

Berkebalikan dengan penelitian dari (Nisa', 2015) yang menyatakan ada hubungan yang signifikan antara konsep diri dengan pembelian impulsif. Hal yang membedakan adalah, dalam teori konsep diri dalam budaya menurut Burns (dalam Saliyo, 2012) terdapat independensi konsep diri yang biasa ditanamkan oleh budaya orang barat dimana mereka menghargai setiap individu untuk berekspresi, memiliki otonomi dan ruang umum yang orang lain tidak peduli dan menghargainya sebagai hak. Dalam pelatihan yang diberikan oleh peneliti pada subyek, terdapat unsur-unsur independent self concept tersebut yang justru dalam penelitian Kacen dan Lee (Kacen \& Lee, 2002) individu dengan konsep diri tersebut memiliki tingkat pembelian impulsif yang lebih tinggi.

Dalam pelatihan, peneliti menekankan independensi dalam contoh-contoh kasusnya, seperti pada menanamkan konsep diri positif dalam kondisi apapun, walaupun bertato dan tubuh gemuk, remaja berhak memiliki masa depan yang cerah sehingga peneliti menekankan remaja agar bisa menerima dan menggali sisi positif mereka yang lain.

Sebaliknya menurut Burns pada konsep diri yang interdepensi terdapat pada budaya orang asia yang terlahir dengan budaya patembayan, gotong royong dan ada rasa serba salah jika berekspresi (dalam Saliyo, 2012) kurang diterapkan pada pelatihan konsep diri yang diberikan pada subyek untuk melihat apakah memang terdapat pengaruh di dalamnya.

\section{Kesimpulan}

Berdasarkan hasil penelitian dan pembahasan di bab sebelumnya menunjukkan bahwa tidak ada pengaruh antara pelatihan konsep diri terhadap kecenderungan pembelian impulsif pada remaja akhir di Kota Tulungagung. Hasil penelitian ini menunjukkan bahwa pelatihan konsep diri tidak terbukti 
menurunkan intensitas perilaku kecenderungan pembelian impulsif pada remaja akhir di Kabupaten Tulungagung.

\section{Daftar Pustaka}

Agustiani, H. (2009). Psikologi Perkembangan: Pendekatan Ekologi Kaitannya dengan Konsep Diri dan Penyesuaian Diri pada Remaja. Bandung: PT. Refika Aditama.

Aini \& Anisa (2018). Demi Belikan HP untuk Sang Anak, Seorang Ibu di Surabaya Rela Menjual Ginjalnya. Tribunnews Online. Diakses dari http://www.tribunnews.com/regional/2018/03/07/demi-belikan-hp-untuk-sang-anak-seorang-ibudi-surabaya-rela-menjual-ginjalnya.

Besouh, N. \& Belkhir, D.O. (2018). The Effect of Mood on Impulse Buying Behavior - Case of Algerian Buyers. Austin Journal of Business Administration and Management. 2(1): 1023

Burns, R.B. (1993). Konsep Diri: Teori, Pengukuran, Perkembangan dan Perilaku. Jakarta: Penerbit Arcan.

Cialdini, R.B., \& Goldstein, N.J. (2004) Social influences: Compiliance and comformity. Annual Review of Psychology, 55, 591-621.

Dell'osso B., Allen A., Altamura A.C., Buoli M., \& Hollander E. (2008). Impulsive-Compulsive Buying Disorder: Clinical Overview. Australian and New Zealand Journal of Psychiatry. 42 (4):259-66. https://doi.org/10.1080/00048670701881561.

Desmita (2011). Psikologi Perkembangan Peserta Didik. Bandung: PT Remaja Rosdakarya.

Diskominfo Tulungagung (2018). Data dan Statistik Ekonomi Kabupaten Tulungagung. Dinas Komunikasi dan Informasi Tulungagung, diakses tanggal 2 Agustus 2019 dari http://tulungagung.go.id/wp-content/uploads/2019/01/Data-dan-Statistik-Ekonomi-2018.pdf

Elias, M.J., Tobias, S.E., \& Friedlander, B.S. (2004). Cara-cara Efektif Mengasah EQ Remaja: Mengasuh dengan Cinta, Canda dan Disiplin. Bandung: Penerbit Kaifa PT Mizan Pustaka

Enrico, A., Aron, R. \& Oktavia, W. (2014). The factors that influenced consumptive behavior: a survey of university students in Jakarta. International Journal of Scientific and Research Publications, 4(1). Diakses dari http://www.ijsrp.org/research-paper-0114/ijsrp-p2518.pdf. tanggal 30 Desember 2018.

Fauzia, M. (2018). Perilaku Konsumtif Masyarakat Turut Sebabkan Rupiah Anjlok. Kompas Online. Diakses dari https://ekonomi.kompas.com/read/2018/09/06/170057026/perilaku-konsumtifmasyarakat-turut-sebabkan-rupiah-anjlok pada tanggal 1 Februari 2019.

Firdaus, D., \& Yusuf, U. (2017). Hubungan antara Self Esteem dengan Impulsive Buying (Studi pada Mahasiswi Fakultas Ilmu Komunikasi yang Berbelanja Melalui Instagram). Prosiding Psikologi, vol 4, no 1, ISSN:2460-6448.

Hatane, S. \& Foedjiwati (2005). Pengaruh kepuasan konsumen terhadap kesetiaan merk. Artikel Universitas Kristen Petra Surabaya. pp. 74-82

Hawkins, D.I., Best, R.J. \& Coney, K.A. (2001) Consumer Behavior Building Marketing Strategy, Tenth Edition, International Edition, McGraw Hill.

Henrietta, P. (2012). Impulsive buying pada dewasa awal di Yogyakarta. Jurnal Psikologi Universitas Diponegoro, 11(2), 1-6. Diakses dari https://ejournal.undip.ac.id/index.php/psikologi/article/view/6696.

Hurlock, E.B. (1990). Developmental Psychology: a Lifespan Approach. (terjemahan oleh istiwidayanti). Jakarta: Erlangga Gunarsa.

Hurlock, E.B. (2004). Psikologi Perkembangan: Suatu Perkembangan Sepanjang Rentang Kehidupan (Edisi Kelima). Jakarta: Erlangga.

Ibrahim, M.F. \& Ng, C.W. (2002). Determinant of entertaining shopping experiences and their link to consumer behaviour: case studies of shopping centres in Singapore. Journal of Leisure Properties Management. Vol. 2, No. 4, pp. 338-357.

Iskandar (2018). Orang Indonesia Habiskan Rp 146 Triliun untuk Berbelanja Online. Liputan6 online. Diakses dari https://www.liputan6.com/tekno/read/3326217/orang-indonesia-habiskan-rp-146triliun-untuk-belanja-online.

Jatmiko, B.P. (Agustus, 2015). OJK. Orang Indonesia Makin Konsumtif. Kompas Online. Diakses dari https://ekonomi.kompas.com/read/2015/08/08/110746226/OJK.Orang.Indonesia.Makin.Konsumtif.

Kacen, J.J. \& Lee, J.A (2002). The influence of culture on consumer impulsive buying behavior. Journal of consumer psychology. 12(2):163-76. 
Khawaja, L. (2018). Factors Influencing Consumer Behavior toward Impulse Buying. Journal in Researchgate. Diakses dari https://www.researchgate.net/publication/329013866.

Lesmana, T. (2017). Hubungan antara Mindfulness dan pembelian impulsif pada Remaja Perempuan yang Melakukan Shopping Online. Jurnal Psibernetika. Vol 10 (2): 81-91. ISSN 1979-3707. Versi Online : http://journal.ubm.ac.id e-ISSN 2581-0871.

Loudon, D.L, \& Bitta, D. (1993), Consumer Behavior: Concepts and Application, Singapore: Mc.GrowHill, Inc.

Maharani (2018). Fenomena Demam Coffee Shop. Kumparan online. Diakses dari https://kumparan.com/@kumparanfood/fenomena-mewabahnya-demam-coffee-shop-di-indonesia.

Mahesa (2018). Siswa SMK di Bangkalan Nekat Mencuri Motor untuk Membeli HP. Berita Online Maduracorner. Diakses dari https://www.maduracorner.com/siswa-smk-di-bangkalan-nekatmencuri-motor-untuk-membeli-hp/.

Mowen, J.C. \& Minor, M. (2002). Perilaku Konsumen: Jilid 2. Edisi 5. Jakarta: Erlangga.

Muslihah. (2017). Mengaku Ingin Baju Baru, Tiga Remaja Jadi Pelaku Begal. Berita Online Kompas. Diakses dari https://regional.kompas.com/read/2017/09/28/23230131/mengaku-ingin-beli-bajubaru-tiga-remaja-jadi-pelaku-begal.

Nisa', L.K. (2015). Hubungan konsep diri dengan pembelian impulsif (impulsive buying) produk pakaian pada mahasiswi UIN MALIKI Malang. Undergraduate thesis, Universitas Islam Negeri Maulana Malik Ibrahim. Diakses dari http://etheses.uin-malang.ac.id/1656/.

Oping, N., Lapian, S.L.H.V., Joice \& Soegoto, A.S. (2015). Pengaruh Faktor Psikologis Konsumen Terhadap Impulsif Buying pada Produk Konsumsi Rumah Tangga di Sakura Mart Amurang. Jurnal EMBA. ISSN 2303-1174 Vol.3 No.4, 104-116.

Peter, J. P., \& Olson, J. C. (2005). Consumer Behaviour and Marketing Strategy (7th ed). New York: McGraw-Hill.

Putera, A.D. (2018). Jumlah Pembeli Online Indonesia Capai 119 persen dari Populasi. Diakses dari https://ekonomi.kompas.com/read/2018/09/07/164100326/jumlah-pembeli-online-indonesia-capai119-persen-dari-populasi.

Primadhyta, S. (2015). dalam cnnindonesia. Diakses dari https://www.cnnindonesia.com/ekonomi/20151102182452-92-88999/generasi-millenial-ri-palingimpulsif-belanja-barang-mewah pada tanggal 1 Februari 2019.

Rakhmat, J. (2005). Psikologi Komunikasi. Bandung: PT. Remaja Rosdakarya.

Rook, D.W. (1987). The Buying Impulse. The Journal of Consumer Research, Vol. 14, No. 2, 189-199.

Rook, D.W. \& Gardner, M.P. (1987) Affective Antecedents to Impulse Buying Behavior. Working Paper, New York University. New York: NY 1003.

Saliyo (2012). Konsep Diri dalam Budaya Jawa. Buletin Psikologi Fakultas Psikologi Universitas Gadjah Mada. Vol. 2 N0.1-2 ISSN 0854-7108.

Schiffman, LG. \& Kanuk, LL. (2004). Consumer behavior, 8th International edition. Prentice Hall.

Seniati, L., Yulianto, A., \& Setiadi, B.N. (2011). Psikologi Eksperimen. Jakarta: PT Indeks.

Setiadi, N.J. (2003), Perilaku Konsumen Konsep dan Implikasi untuk Strategi dan Penelitian Pemasaran. Jakarta: Kencana.

Sugiyono. (2009). Metode Penelitian Kuantitatif, Kualitatif dan R\&D. Bandung: Alfabeta.

Swaratunaiku. (2016). Ternyata Milenial itu Suka Impulsif Waktu Belanja. Diakses dari https://swara.tunaiku.com/gayahidup/ternyata-millenial-itu-suka-impulsif-sewaktu-belanja.

Verplanken, B. \& Herabadi, A. (2001) Individual Differences in Impulse Buying Tendency: Feeling and No Thinking. European Journal of Personality, 15, S71-S83. http://dx.doi.org/10.1002/per.423.

Virvilaite, R. \& Saladiene, V. (2012). Models investigation of factors affecting consumer impulsive purchase behavior in retail environment. Journal of Economics and Management, 17 (2). Diakses dari http://www.ecoman.ktu.lt/index.php/Ekv/article/viewFile/2196/1706 pada tanggal 14 Januari 2018

Vohs, K.D., \& Faber, R.J. (2007). Spent resources: Self-regulatory resource availability affects impulse buying. Journal of Consumer Research, 33(4), 537-547. https://doi.org/10.1086/510228. 